\title{
Scientists in the public sphere: Interactions of scientists and journalists in Brazil
}

\author{
LUISA MASSARANI and HANS P. PETERS \\ Museu da Vida, Casa de Oswaldo Cruz, Fundação Oswaldo Cruz, Av. Brasil, \\ 4365, Manguinhos, 21040-900 Rio de Janeiro, RJ, Brasil \\ Manuscript received on July 23, 2015; accepted for publication on March 1, 2016
}

\begin{abstract}
In order to map scientists' views on media channels and explore their experiences interacting with journalists, the authors conducted a survey of about 1,000 Brazilian scientists. Results indicate that scientists have clear and high expectations about how journalists should act in reporting scientific information in the media, but such expectations, in their opinion, do not always seem to be met. Nonetheless, the results show that surveyed scientists rate their relation with the media positively: $67 \%$ say that having their research covered by media has a positive impact on their colleagues. One quarter of the respondents expressed that talking to the media can facilitate acquisition of more funds for research. Moreover, $38 \%$ of the total respondents believe that writing about an interesting topic for release on media channels can also facilitate research publication in a scientific journal. However, $15 \%$ of the respondents outright agree that research reported in the media beforehand can threaten acceptance for publication by a scientific journal. We hope that these results can foster some initiatives for improving awareness of the two cultures, scientists and journalists; increasing the access of journalists to Brazilian scientific endeavors; stimulating scientists to communicate with the public via social networks.
\end{abstract}

Key words: Brazil, Interactions of scientists and journalists, Public communication of science and technology, Science communication, Science journalism.

\section{INTRODUCTION}

In many instances, the interaction between scientists and journalists has been deemed difficult with many communication barriers (e.g. Hartz and Chappell 1997). A study of US scientists by Dunwoody and Ryan (1985) shows that some scientists do not want to extend communication beyond the borders of science or that they even disapprove of their colleagues who communicate their research within the public sphere. Science journalist Ivanissevich

Correspondence to: Luisa Massarani

E-mail: luisa.massarani4@gmail.com
(2014), editor of the Brazilian magazine Ciência Hoje, highlights that scientists and journalists live in different worlds, with a "real cultural shock", that they inevitably battle.

However, some sectors call for the improvement of relationships between scientists and the media. In 1985, the Royal Society published an iconic document to move in that direction. The so-called Bodmer Report warned that "scientists must learn to communicate with the public, be willing to do so, and indeed consider it their duty to do so" (The Royal Society 1985, p. 8). The report highlights the following: 
"All scientists need, therefore, to learn about the media and their constraints and learn how to explain science simply, without jargon and without being condescending. Each sector of the scientific community should consider, for example, providing training on communication and greater understanding of the media, arranging non-specialist lectures and demonstrations, organizing scientific competitions for younger people, providing briefings for journalists and generally by improving their public relations." (The Royal Society 1985 , p. 8).

Recent studies show a decrease in the perception of existing communication "barriers" between scientists and journalists. For example, a survey conducted by Peters et al. (2008) revealed that interactions between media and scientists in five top R\&D countries (Germany, France, Japan, UK and USA) are more frequent and smoother than previously thought. According to Peters (2013a, b), there is an increasing strategic orientation of science toward the media today.

In the last decade, Brazil has incentivized scientists to communicate their research to the public. The creation of the Department for Popularisation of Science and Technology within the Brazilian Ministry of Science, Technology and Innovation in 2004 illustrates these efforts. Since then, the Department has been responsible for helping design a policy for science communication in Brazil, including funding for science communication projects. In addition, some actions have been undertaken to sensitize scientists for communicating science with the public. The National Council for Science and Technology (CNPq), which is linked to the Ministry of Science, Technology and Innovation, created a specific committee for science communication which works along the lines of other knowledge areas; that is, its objective is to set up and put in practice guidance for supporting research and, in this case, practice in the area. In 2012, CNPq also created a specific section for generating visibility of science communication activities in its national online platform (the Lattes Platform), where CVs of Brazilian scientists as well as scientists working in Brazil are made publicly available.

\section{MATERIALS AND METHODS}

To map scientists' views on the media and explore their experiences in interacting with journalists, we held a survey of about 1,000 Brazilian scientists. For sample selection, we focused on the Lattes Platform, an online database created by the National Council for Science and Technology (CNPq), the most important research funding agency linked to the Ministry of Science, Technology and Innovation. Everyone in Brazil (from undergraduate students to senior fellowships) who seeks a grant or a fellowship from CNPq is registered in the database. Most of the decisions made by the CNPq in relation to research support activities are based on the information from this database, providing a clear stimulus for keeping the information updated. The database has received such recognition in the scientific community that other funding agencies (at both federal and state levels) as well as research institutions use it as a reference for making their own decisions for support, contexts, evaluation, etc.

Because it is so important, the database is also massive. The number of CVs uploaded in the system by Ph.D.s doing research and teaching in Brazil is approximately 119,402 . Registered scholars with a Masters degree come to another 82,136 additions to the database ${ }^{1}$. Furthermore, the search system includes every person who filled out the registration information, even if he/she is not currently working as researcher. Therefore, an important challenge in our research was to create strategies for collecting data from people who are actually active and

\footnotetext{
${ }^{1}$ Source <http://estatico.cnpq.br/painelLattes/mapa/> (accessed on June 26, 2015).
} 
directly involved in research practice. To meet this challenge, we decided to focus on a specific group called "Bolsistas Produtividade" (Productivity Fellows), an award "targeted to researchers who have prominence among their peers, highlighting their scientific production following normative criteria established by the CNPq" ${ }^{2}$. The selection of Productivity Fellows includes a peer-review process with general criteria established by $\mathrm{CNPq}$ including:

a) The candidate's scientific production

b) Participation in human resources training in post-graduate courses

c) Contribution to science, technology and innovation

d) Role as coordinator or Principal investigator (PI) in research projects

e) Participation in editorial and scientific management activities in institutions and nuclei of scientific and technological excellence.

There are two categories for Productivity Fellows: Researcher 1 requires at least eight years of holding a Ph.D. by the time the Fellowship is implemented. This category includes 4 levels (A to D), which are categorized based on a comparison between the candidate and his/her peers as well as data from the previous 10 years. Researcher 2 requires at least three years of holding a $\mathrm{Ph} . \mathrm{D}$. by the time the Fellowship is implemented.

Those who are awarded this fellowship receive a monthly stipend to conduct research, plus an additional salary stipend. Furthermore, participation in the Fellowship program is a status symbol since it means that scientists are well recognised by their peers, which in turn facilitates acquisition of other funding resources.

The study sample was drawn from a total of 15,000 Productivity Fellows in the CNPq database, considering their knowledge domain area, their

\footnotetext{
2 Source <http://www.cnpq.br/documents/10157/5f43cefd-
} 7a9a-4030-945e-4a0fa10a169a > (accessed on June 26, 2015). fellowship level and their gender. From the total of 2,854 scientists who received the invitation to participate in this study, 956 of them answered the survey, representing a response rate of $33.5 \%$.

According to their knowledge domain area, respondents included in the sample are categorized as follows: $35.0 \%$, Engineering, Exact \& Earth sciences; $23.6 \%$, Humanities \& Social sciences; $41.3 \%$, Life-Health sciences. In terms of Productivity Fellowship level, the distribution was $6.7 \%$, PQ-1A (higher status); 8.1\%, PQ-1B; 7.4\%, PQ$1 \mathrm{C} ; 13.3 \%$, PQ-1D; $64.0 \%$, PQ-2. In respect to gender, $63.4 \%$ of the respondents were men and $36.6 \%$, women. Because of this sampling procedure, study results are potentially only related to this sample and, therefore, not necessarily generalizable to the whole Brazilian scientific community. On the other hand, they do show trends key professionals' perspectives with respect to media and explore scientist experiences in interacting with journalists among a broad range of highly productive scientists from around the country.

The questionnaire followed the same structure as that of one designed by a team in the Jülich Research Center. It was translated into Portuguese and made available online, from May to July 2013. All responses were anonymous. In the next section, we present the general results of this study. Two other papers (in preparation) specifically consider scientists gender, age and knowledge domain areas and whether these dimensions affect their views on scientists' relationships with the media.

\section{RESULTS}

EXPECTATIONS FOR HOW SCIENTISTS AND JOURNALIST SHOULD ACT

One set of questions has to do with respondents' expectations of how scientists should act with media contacts. We asked the respondents to indicate the level of agreement or disagreement with the following statements (Table I): 
TABLE I

Level of agreement of how scientists should act with media contacts*.

\begin{tabular}{lc}
\hline With media contacts, scientists should . . . & Mean \\
\hline if asked, provide information about current research or research that has not yet appeared in scientific publications. & 0.13 \\
\hline communicate their results and expertise in an entertaining manner. & 1.66 \\
\hline not share internal scientific differences of opinion with the general public. & -0.61 \\
\hline use catchy phrases that can be quoted verbatim by reporters. & -0.81 \\
\hline $\begin{array}{l}\text { if asked, speak openly about problems, such as misconduct on the part of researchers or controversial research } \\
\text { practices. }\end{array}$ & 0.37 \\
$\begin{array}{l}\text { use their expertise to criticize political, economic, and other decisions affecting society or make practical suggestions } \\
\text { for action. }\end{array}$ & 1.23 \\
\hline play along if journalists are not only interested in scientific results, but are also interested in them personally. & -1.61 \\
\hline schedule a lot of time. & -0.52 \\
\hline relate their research to the everyday experience of the media public. & 0.82 \\
\hline *The level of agreement is measured on a 5-step scale ranging from -2 (Completely disagree) to +2 (Completely agree), plus a \\
$\begin{array}{l}\text { category "Don't know". The lower the mean, the less agreement is recorded in relation to the statements; the higher the mean, the } \\
\text { more agreement is observed toward the statements. }\end{array}$
\end{tabular}

Respondents agree that scientists should communicate their results and expertise in an entertaining manner - but not using "catchy" phrases that can be quoted verbatim by reporters. They strongly agree that scientists should use their expertise to criticize political, economic, and other decisions affecting society or to make practical suggestions for action, but the answers show some concern about how far scientists can go when speaking about things beyond their expertise. For example, they strongly disagree that scientists should "play along" if journalists are not only interested in scientific results, but are also interested in them personally. There is some agreement that scientists, if asked, should speak openly about problems, such as misconduct on the part of researchers or controversial research practices and share internal scientific differences of opinion with the general public. To relate their research to the everyday experience of the media public is also acceptable. Respondents appear to be somewhat ambivalent as to whether scientists should "if asked, provide information about current research or research that has not yet appeared in scientific publications". The respondents express an unwillingness to dedicate "a lot of time" for journalists - although the question does not clarify what "a lot of time" means.
Another set of questions had to do with the expectations respondents have for how journalists should report on science. Additionally, they were asked to indicate whether they think journalists typically act in accord with these expectations, given that they had any relevant experience. They were also asked to indicate the extent to which they agree or disagree with statements about requirements journalists need to meet (Table II).

The results indicate that for four out of eight statements, the respondents have high expectations for how journalists should act in reporting science: they believe journalists should consult the scientists they have interviewed prior to publication in order to avoid making factual errors; avoid compromising scientific accuracy in what they report; support scientists in educating the general public; and report about research methods and processes so that the general public can understand the reasons for scientific claims - expectations that seem not to be met from their perspective.

\section{INTERACTING WITH THE MEDIA}

About $80 \%$ of the respondents affirm that they have had contact with the media in the prior three years. Approximately $70 \%$ of the total respondents never refused to give information to journalists who 
TABLE II

Level of agreement on how scientists should act with media contacts, how journalists should report on science, and whether journalists typically act accordingly*.

\begin{tabular}{|c|c|c|}
\hline Journalists should ... & Agreement (mean) & $\begin{array}{c}\text { Whether journalists } \\
\text { typically act } \\
\text { accordingly (\% of } \\
\text { disagreement) }{ }^{2} \%\end{array}$ \\
\hline $\begin{array}{l}\text { report about research methods and processes so that the general public can } \\
\text { understand the reasons for scientific claims. }\end{array}$ & 1.51 & $53 \%$ \\
\hline $\begin{array}{l}\text { consult the scientists they have interviewed prior to publication in order to avoid } \\
\text { making factual errors. }\end{array}$ & 1.84 & $65 \%$ \\
\hline $\begin{array}{l}\text { acknowledge that scientific expertise is more credible than the knowledge of } \\
\text { practitioners based on professional experience. }\end{array}$ & 0.35 & $47 \%$ \\
\hline $\begin{array}{l}\text { only report on research results that have already appeared in scientific } \\
\text { publications. }\end{array}$ & 0.06 & $47 \%$ \\
\hline select their interviewees based strictly on the criterion of professional reputation. & 0.74 & $42 \%$ \\
\hline support scientists in educating the general public. & 1.72 & $40 \%$ \\
\hline only ask scientists about topics on which they have done research themselves. & 0.45 & $51 \%$ \\
\hline avoid compromising scientific accuracy in what they report. & 1.72 & $61 \%$ \\
\hline \multicolumn{3}{|c|}{$\begin{array}{l}\text { *The level of agreement is measured on a } 5 \text {-step scale ranging from }-2 \text { (Completely disagree) to }+2 \text { (Completely agree), plus a } \\
\text { category "Don't know." The lower the mean, the less agreement is recorded in relation to the statements; the higher the mean, the } \\
\text { more agreement is observed toward the statements. } \\
2 * \text { The answers in this case were "most cases yes"; "most cases no"; "yes and no - more of less equally often." In this column, we } \\
\text { indicate the answers for "most cases no". }\end{array}$} \\
\hline
\end{tabular}

wanted to interview them; another $29 \%$ respond that they did refuse, and only $0.4 \%$ refused all requests from journalists. Most of the contacts are by request of the journalist (77\%); scientists hardly contact journalists themselves (2.6\%). Sixty-six percent of the scientists report being interviewed by newspaper journalists while $26 \%$ report being interviewed by television journalists.

The results show that scientists rate their relation with the media positively: $66 \%$ report that having their research covered by media has a positive impact on their reputation among scientific colleagues. A further $20 \%$ affirm that the impact is partially positive and partially negative, whereas only $2 \%$ claim that the impact is negative.

About two thirds of the respondents describe the contact with journalists in the prior three years as good, and $23 \%$ had good and bad experiences. Only 4\% report bad experiences. Almost half of the respondents (45\%) find that contact with the media tends to be useful, with the other half finding that it is neither useful nor damaging.
For $24 \%$ of the interviewees, talking to the media facilitates more funding for their research. Thirty-eight percent believe that writing on a topic of interest to the media can also facilitate publication in a scientific journal. Fifteen percent of respondents, believe that acceptance of a publication by a scientific journal can be threatened if the research is reported in the media first; another $22 \%$ partially agree that this is the case.

In terms of perception of quality of media coverage (including newspapers, radio and television), the respondents tend to agree that media coverage is usually inaccurate. Respondents appear to have mixed feelings about whether media use credible scientific sources - a situation closely resembling the answer to the statement about whether media coverage is usually comprehensive enough. Respondents tend to disagree that media coverage is hostile to science.

The results suggest that scientists feel free to decide for themselves whether they give interviews to the media. Neither superiors (69\%), 
units responsible for press relations $(71 \%)$, other departments (81\%), external collaborators (64\%), funders or clients $(64 \%)$, nor political or other authorities $(89 \%)$ determine whether they grant interviews.

\section{OTHER STRATEGIES FOR ENGAGING}

Among respondents, $65 \%$ affirm that they have participated actively in an event such as a talk, a panel discussion or a science exhibition for the general public. Brazilian scientists report not using social media forums as science communication tools: $63 \%$ report that they have not put information related to their research in a website, blog or social network site for the general public in the last 12 months. However, $73 \%$ of the respondents affirmed to be a member of a social network, mostly to be in contact with their friends and relatives $(80 \%)$ or to keep informed about general political, cultural and other public issues (64\%).

Social networks are also tools respondents employ to be informed about public issues related to science in their expertise area $(62 \%)$ or to communicate professionally with other scientists $(65 \%)$. Less than one third (30\%) have a website to which they provide their research or issues on their area of expertise.

SCIENTISTS' VIEWS OF THE PUBLIC?

A further set of questions had to do with the communication between scientists and the public (Table III).

TABLE III

How scientists see the public and their communication with the public*.

\begin{tabular}{|c|c|}
\hline $\begin{array}{l}\text { The following statements contain various positions that may have consequences for communication between } \\
\text { science and the public. What is your opinion about each statement? }\end{array}$ & Mean \\
\hline public communication about science primarily serves to fill the general population's knowledge deficit. & 0.08 \\
\hline greater knowledge on the part of the public leads to more positive attitudes toward science and technology. & 1.56 \\
\hline positive public visibility ensures political support for science. & 1.07 \\
\hline the public's ability to make judgments is sufficient to allow it to participate in decision-making on research policy. & -0.85 \\
\hline $\begin{array}{l}\text { when communicating with the public, it is essential to establish communication as a dialog between two equal } \\
\text { partners. }\end{array}$ & 0.61 \\
\hline the public is not well educated enough to really understand scientific findings. & -0.06 \\
\hline
\end{tabular}

Results indicate a strong belief of respondents that greater knowledge on the part of the public leads to more positive attitudes toward science and technology, and that public visibility of science helps to secure political support. The image of the public in terms of its ability to understand scientific findings among scientists is neither clearly positive nor negative, the demand for public participation in research policy is rejected by most scientists. However, respondents mildly agree to communicate with the public as a "dialog between equal partners" and are not clearly in favour of communication addressing mainly the "knowledge deficit" of the public. Taken together, the answers indicate the perception of clear benefits of public communication of science for science and ambiguity regarding the image of the public and the preferred form of communication with it.

\section{DISCUSSION}

As the results indicate, the respondents to our survey agree that scientists should communicate their results and expertise in an entertaining manner. The answers suggest that scientists accept, at some 
level, that they should adapt their way of speaking for journalists, but only up to a point: using catchy phrases that can be quoted verbatim by reporters which is considered an important strategy by the media to catch audience attention - seems to be not appropriate from the scientists' perspective.

The respondents strongly agree that scientists should use their expertise to criticise political, economic, and other decisions affecting society and to make practical suggestions for action. But the answers show some concerns about how far scientists can go when talking about things beyond their expertise. This finding may have some important impacts on science coverage. For example, the respondents strongly disagree that scientists should play along if journalists are not only interested in scientific results, but are also interested in them personally: studies have shown that scientists are represented both by the media and in the public imagination through the stereotype of the the male scientist in a white lab coat disconnected from society and who is not "normal." This image culminates in the popular culture image of the "mad scientist" (see, for example, Mead and Metraux 1957, Long et al. 2001, Flicker 2003, Rosa et al. 2005, Mesquita and Soares 2008). The perception of scientists that they should not present themselves as human beings with personal interests may be helping to construct this gap between scientists and the public.

According to our results, there is a low level of agreement about whether scientists should speak openly about problems, such as misconduct on the part of researchers or controversial research practices and share internal scientific differences of opinion with the general public. If the scientific community wants to be in fact part of society, scientists need to speak openly about their issues because controversies are part of the development of science, and most Brazilian research is supported by public funds. Furthermore, talking about misconduct - a problem that it is faced not only in science - is required for transparency purposes and for having social control of potential misconduct.

In our study, scientists expressed little agreement with the idea that scientists should provide information about research that has not yet appeared in scientific publications and - along the same lines - believe that journalists should report only on research results that have already appeared in scientific publications. This thinking rests on good ground since papers published by scientific journals have passed through a peer-review process, which, although not foolproof, at least can give some warrantee of quality. One important aspect to keep in mind here, however, is the realm of investigative science journalism, which includes in depth coverage and a critical eye, implying of necessity to have more diversity of sources, including those that are not easily accessible ${ }^{3}$. Furthermore, the items stating a preference for limiting public communication to research already published in scientific journals may be (mis)read as implying that public communication of science should be confined solely to the communication of research findings. This is of course not true. Journalism does not limit its field of coverage to the reporting of research results. Covering science includes not only coverage of newsworthy developments: "behind the scenes" issues and science policies are indeed important to be covered as well and are not reported on in scientific journal papers.

The strong agreement with items stating the important role of scientific publications for the communication of research point to an important issue: the availability of those publications to journalists. Journalists who work in the mainstream media do not necessarily have easy access to papers: most researchers working in Brazilian universities

\footnotetext{
${ }^{3}$ An interesting article in this regard is "How to be an investigative science journalist", by K. S. Jayaraman, published by SciDev.Net, available at http://www.scidev.net/global/ communication/practical-guide/how-to-be-an-investigativescience-journalist-1.html (accessed on July 5, 2015).
} 
and research institutions do have, in the last decade, access to the main international journals through the so-called "Portal da Capes", a funding agency linked to the Ministry of Education - but this is not the case for journalists. Journals such as Science, Nature and JAMA do have a very good system for distributing their papers worldwide to journalists, including Brazilians. Recognising the importance of this system, Oliveira et al. (2014) - who analised the influence of this system in two key Brazilian newspapers - highlight that these journals present mostly research carried out in the US, UK and in the so called Developed World, configuring "a partial and geographically limited view of the world science" that does "not necessarily meet our social and economic needs" (Oliveira et al. 2014, p. 12). Brazil does have an important initiative for giving visibility to Brazilian science, the Scielo (available at www.scielo.br), a website that links to many Brazilian and Latin American journals. However, the journals sometimes take some time to make available new issues, a considerable obstacle for journalists who require updated information due to the nature of journalistic production. There is, thus, clearly a need for an updated system of distribution of the research produced in Brazil and/or research that is of relevance for the country.

Our results indicate that respondents have high expectations for how journalists should act in reporting science - expectations that seem to be not met. It is interesting to compare scientists expectations for how journalists should act with the expectations of journalists: for example, while there was a high level of agreement among respondents in this survey that journalists should support scientists in educating the general public, a survey among Brazilian science journalists shows that only $4 \%$ of them believe that it is their role to educate the public (Massarani et al. 2014). Instead, journalists understand that their role is to inform the public and to explain complex material in an accessible language. Furthermore, many journalists reject the idea strongly supported by the respondents that journalists should consult the scientists they have interviewed prior to publication in order to avoid making factual errors. An important argument here is the independence of the journalists in their stories, which are under the sphere of their decision (not of scientists). Furthermore, journalists can find different strategies for checking accuracy such as consulting other experts about the research. Having an independent voice in the story also allows journalist to have a more independent story in relation to the scientists who are - in case of factual stories about new advances in science the focus of the stories. This also challenges the view expressed by some of the respondents that journalists should only ask scientists about topics on which they have done research themselves; from a journalism perspective, if an independent voice is required in the stories, scientists should be prepared to comment on the research carried out by other scientists.

Our results are in line with those of a study carried out by Peters (1995), who highlighted the existence of two different professional cultures: the professional culture of scientists and the professional culture of journalists. Peters highlights that value differences between these two cultures are not resolved by being made aware of them. Peters says:

\footnotetext{
"What seems possible by means of intercultural communication training, however, is the better psychological management of frustrations and experiences during contacts with other cultures, and the despersonalisation of conflicts" (Peter 1995, p. 46).
}

An interesting issue raised by our results is the fact that despite the different opinions, scientists in this study rate their relations with the media as mostly positive, expecting a beneficial impact on their reputation - similar to what has been reported for the major 'old' science countries (Peter et al. 
2008) - including making it easier to receive more funds for their research or to get a paper accepted by a scientific journal. About $80 \%$ of the interviewees affirm that they have had contact with the media in the past three years and $65 \%$ affirm that they have participated actively in an event for the general public such as a talk, a panel discussion, or a science exhibition. It is possible that scientists who are more likely to be positive about communicating science were those who were also more committed in answering our survey, which could lead to a bias in the results although the high response rate for the survey suggests that it represents a broad range of scientists and, therefore, experiences. Another paper to be published soon will address this issue, exploring the possible bias caused by the imperfect response rate.

Our results also indicate a clear perception among the respondents that greater knowledge on the part of the public leads to more positive attitudes toward science and technology. However, Castelfranchi et al. (2013), as well as many others, challenge this reasoning, showing that - based on a nationwide survey in Brazil - optimistic attitudes about S\&T do not depend on people's educational level, their level of information, or their access to related subject matter. According to the authors:

"On average, respondents who say they have scarce information on the topic display positive attitudes. Those with a higher educational level and who access information display diverse attitudes, which are optimistic in some regards but more critical in others." (Castelfranchi et al. 2013, p. 1163)

An issue included in our study was the interaction of Brazilian scientists with new online media. According to Peters (2014):

"The traditional relationship between science and journalism is challenged by the rise of new online media. These provide opportunities for scientists and scientific organisations to communicate directly with the public via websites, blogs and social networks. Science journalism may be entering a critical period but it is unlikely that it will fall into decline or be replaced by these new science communications media." (Peters 2014, p. 163)

According to a report produced by the 360i's Insights \& Planning group, Brazil is emerging as one of South America's most social-media savvy countries, with $79 \%$ of Internet users already active on social platforms (an adoption rate that is fast approaching that of the United States) ${ }^{4}$.

At the same time, although the general scenario and the survey results show high levels of social media use, scientists are still not engaged with social media forums as science communication tools: $63 \%$ said they had not put information related to their research in a website, blog or social network site for the general public in the last 12 months. These results are in contrast with the fact that $73 \%$ of the respondents affirmed to be a member of a social network, mostly to be in contact with their friends and relatives or to keep informed about general political, cultural and other public issues. In other words, they are active in social networks, but they do not use them to communicate their research. This means that scientists are losing a good opportunity to communicate their research directly with the public.

In this paper, we have mapped scientists' views on the media and explored their experiences in interacting with journalists in Brazil. As we mentioned before, the results are related to the sample of researchers as detailed in the section of the methodology in this paper and, as such, may not necessarily be generalisable to the whole Brazilian scientific community. On the other hand, they show the trends in the views of the media held by scientists and explore their experiences in interacting

\footnotetext{
${ }^{4}$ See http://www.360i.com/reports/global-twitter-trendsbrazil/ (accessed on July 5, 2015).
} 
with journalists. As a quantitative study, we gain a general panorama of their views, which will be explored further in the next steps, aiming to understand whether the views vary according to scientific domains and to compare the findings with those of international surveys carried out by the Research Center Jülich. A qualitative step involving in depth interviews will also be carried out, aiming to understand some of our results more fully. As far as we know, this is the first survey of its kind in Brazil. Follow-up studies in coming years may help to document how much the views change (or not) in long term. Among other things, we hope that this study can foster some initiatives for improving awareness of the two cultures from the side of both scientists and journalists, increasing journalists' access to Brazilian science, and stimulating scientists to communicate further with the public via social networks.

\section{ACKNOWLEDGMENTS}

This research is being supported by the Conselho Nacional de Desenvolvimento Científico e Tecnológico (CNPq)/ Ministério da Ciência, Tecnologia e Inovação (MCTI) (CNPq 470310/2013-8). We thank Ana Paula Trindade for her help in collecting the data for this research and Petra Degen for her help in programming the questionnaire and online field work.

\section{RESUMO}

Para mapear as visões de cientistas sobre a mídia e explorar suas experiências na interação com jornalistas, realizamos uma enquete com cerca de mil cientistas brasileiros. Os resultados indicam que os respondentes têm expectativas claras e altas em relação a como os jornalistas deveriam atuar quando cobrem temas de ciência e tecnologia - expectativas que parecem, na opinião deles, não estar sendo satisfeitas. Ainda assim, os resultados mostram que os cientistas que responderam nossa enquete avaliam positivamente suas relações com a mídia: $67 \%$ afirmam que o fato de sua pesquisa ter sido coberta pela mídia tem um impacto positivo entre seus colegas cientistas. Um quarto dos entrevistados expressou que falar com a mídia pode até mesmo tornar mais fácil ter acesso a apoio econômico para sua pesquisa. Do total, $38 \%$ acreditam que escrever sobre um tópico interessante para a mídia pode também tornar mais fácil ter um artigo aceito por um periódico científico. Para $15 \%$ dos entrevistados, a aceitação de um artigo por um periódico científico pode estar ameaçada se a mídia tiver previamente divulgado o estudo. Esperamos que este estudo possa estimular iniciativas para, entre outras, melhorar o conhecimento mútuo das duas culturas, por parte tanto de cientistas como jornalistas; aumentar o acesso de jornalistas a ciência brasileira; estimular cientistas a se comunicarem mais com o público por meio das mídias sociais.

Palavras-chave: Brasil, Interações de cientistas e jornalistas, Jornalismo científico, Comunicação pública da ciência e tecnologia, Divulgação científica.

\section{REFERENCES}

CASTElFranchi Y, Vilela EM, MOREIRA I AND MASSARANI L. 2013. Brazilian opinions about science and technology: the 'paradox' of the relation between information and attitudes. História, Ciências, SaúdeManguinhos 20: 1163-1183.

DUNWOODY S AND RYAN M. 1985. Scientific Barriers to the Popularization of Science in the Mass Media. J Commun 35: $26-42$

FLICKER E. 2003. Between Brains and Breasts - Women Scientists in Fiction Film: On the Marginalization and Sexualization of Scientific Competence. Public Underst Sci 12: 307-318.

HARTZ J AND CHAPPELL R. 1997. Worlds Apart: How the Distance Between Science and Journalism Threatens America's Future. First Amendment Center. Nashville. Available at http://www.firstamendmentcenter.org/ madison/wp-content/uploads/2011/03/worldsapart.pdf (accessed on June 26, 2015).

IVANISSEVICH A. 2014. Desafios do jornalismo de ciência - Como comunicar ciência com qualidade? Available at http://pt.slideshare.net/henriquekugler/desafios-dojornalismo-de-cincia-como-comunicar-cincia-comqualidade (accessed on June 26, 2015)

LONG M, BOIARSKY G AND THAYER G. 2001. Gender and racial counter-stereotypes in science education television: a content analysis. Public Underst Sci 10(3): 255-269.

MASSARANI L. 2014. Science Comunication in Latin America: What's going on? Science Museum Group Journal 2: 6. 
MEAD M AND MetrauX R. 1957. Image of the Scientist among High-School Students: a pilot study. Science 126(3270): 384-390.

MESQUiTA N AND SOARES M. 2008. Visões de ciência em desenhos animados: uma alternativa para o debate sobre a construção do conhecimento científico em sala de aula. Ciênc Edu 14(3): 417-429.

OLIVEIRA S, MASSARANI L AND AMORIM L. 2014. Ciência sob embargo: um estudo de caso dos jornais O Globo e Folha. E-Compós 17: 1-18. Available at http://www.compos. org.br/seer/index.php/e-compos/article/viewFile/982/748 (accessed on July 20, 2015)

PETERS HP. 1995. The interaction of journalists and scientific experts: co-operation and conflict between two professional cultures. Media, Cult Soc 17(1): 31-48.

PETERS HP. 2013a. Gap between science and media revisited: Scientists as public communicators. P Natl Acad Sci 110(Suppl. 3): 14102-14109.
PETERS HP. 2013b. The two cultures: Scientists and journalists, not an outdated relationship. Métode: 80: 163-169. Available at https://ojs.uv.es/index.php/Metode/article/ view/3043/3546 (accessed on June 26, 2015).

PETERS HP. 2014. The two cultures: Scientists and journalists, not an outdated relationship. In: Métode, No. 80, p. 49-55. doi: 10.7203/metode.80.3043.

Peters HP, Brossard D, CheVeigné S, Dunwoody S, KALLFASS M, MiLler S AND TSUCHIDA S. 2008. Science Communication: Interactions with the mass media. Science 321(5886): 204-205.

ROSA MIP ET AL. 2005. Os cientistas nos desenhos animados e os olhares das crianças. In: Anais do V Encontro Nacional de Pesquisa em Educação em Ciências, Bauru, SP.

THE Royal Society. 1985. The Public Understanding of Science: Report of a Royal Society ad hoc Group endorsed by the Council of the Royal Society. London: Royal Society. 